\title{
Epithelial-to-Mesenchymal Transition
}

National Cancer Institute

\section{Source}

National Cancer Institute. Epithelial-to-Mesenchymal Transition. NCI Thesaurus. Code C97304.

A cellular process where an epithelial cell loses polarity, disassembles adhesive junctions, degrades its basement membrane and transforms into a migratory mesenchymal cell. 